Original Research Paper

\title{
Uji Toksisitas Escherichia coli Asal Daging Terhadap Sel Vero
}

\author{
Widodo Suwito $^{1 *}$ Andriani $^{2}$ \\ ${ }^{1}$ Balai Pengkajian Teknologi Pertanian Yogyakarta \\ J1. Stadion Baru Maguwoharjo No. 22. Karang Sari, Wedomartani, Ngemplak, Sleman, Yogyakarta, Indonesia, 55584 \\ ${ }^{2}$ Balai Besar Penelitian Veteriner \\ J1. R.E. Martadinata No.30 Kotak Pos 151, Bogor, Indonesia, 16124
}

Article history

Received: 18 September 2018

Revised: 29 Oktober 2018

Accepted: 1 Desember 2018

Published: 12 Desember 2018

*Corresponding Author:

Widodo Suwito,

Balai Pengkajian Teknologi

Pertanian Yogyakarta

J1. Stadion Baru Maguwoharjo

No. 22. Karang Sari,

Wedomartani, Ngemplak,

Sleman, Yogyakarta,

Indonesia, 55584

Email:

widodo.suwito@yahoo.com
Abstract: Verotoxigenic Escherichia coli (VTEC) is responsible for serious human illnesses. Source of VTEC is cattle faeces which beef contamination. The aims of this study was to determine the ability of $E$. coli which beef contamination from traditional market to damage the vero cells monolayer. A total of $35 \mathrm{E}$. coli isolates and vero cells monolayer were used in these study. All isolates $E$. coli were re-indentified with biochemistry and vero cells monolayer were uesed to determination verotoxigenecity tests. None of $E$. coli isolates showed damage the vero cells monolayer, so there are not verotoxigenik $E$. coli. The study showed that all isolate $E$. coli which beef contamination from tradiotional market none damage the vero cells, so there are not verotoxigenic.

Key words: $E$.coli, beef, vero cell

Abstrak: Escherichia coli verotoksigenik (VTEC) menyebabkan penyakit pada manusia. Sumber VTEC adalah feses sapi yang dapat mengkontaminasi daging. Tujuan penelitian ini adalah mengetahui kemampuan $E$. coli yang diisolasi dari daging sapi di pasar tradisional dalam merusak sel vero monolayer. Sebanyak 35 isolat $E$. coli dan sel vero monolayer digunakan dalam penelitian ini. Isolat $E$. coli di identifikasi ulang secara biokimia dan untuk menentukan sifat verotoksigenesitasnya menggunakan sel vero monolayer. Semua isolat $E$. coli tidak bersifat verotoksigenik karena tidak mampu merusak sel vero. Penelitian ini menunjukkan bahwa $E$. coli yang mengkontaminasi daging sapi dari pasar tradisional tidak bersifat verotoksigenik.

Kata kunci: E.coli, daging, sel vero.

\section{Pendahuluan}

Escherichia coli merupakan bakteri Gram negatif, berbentuk batang pendek, bersifat anerob fakultatif, tidak berspora, dan banyak terdapat di lingkungan sekitar kita (Gomes et al., 2011). Sebagian besar E. coli berada dalam saluran pencernaan hewan dan manusia sebagai flora normal, tetapi ada yang bersifat patogen yang dapat menyebabkan diare pada manusia. Berdasarkan mekanisme infeksi $E$. coli dalam menimbulkan penyakit, maka Nataro et al., (2004) membagi menjadi 5 kelompok yaitu: Enteropathogenic E. coli (EPEC), Enterotoxigenic E. coli (ETEC), Enterohemorrhagic E. coli (EHEC), Enteroaggregative
E. coli (EaggEC) dan Enteroinvasive E. coli (EIEC). Escherichia coli memiliki beberapa antigen yang berperan dalam patogenesis seperti antigen somatik, flagella, kapsular, fimbriae, enterotoksin, dan verotoksin.

Escherichia coli verotoksigenik (VTEC) merupakan salah satu strain yang mampu merusak sel Vero (African Green Monkey Kidney) karena menghasilkan verotoksin (Konowalchuk et al., 1977). Verotoksin merupakan toksin yang dihasilkan oleh $E$. coli yang bersifat heat labile dan in aktif pada suhu $72^{\circ} \mathrm{C}$ selama 16,2 detik atau $70^{\circ} \mathrm{C}$ selama 2 menit. Mekanisme kerja verotoksin yaitu menghambat sintesis protein dengan in aktifasi 60s ribosom sub unit 28S RNA (Nataro et al., 2004). Sementara itu, Karmali et al, (2010) menyatakan bahwa dampak infeksi VTEC pada 
manusia antara lain hemorrhagic colitis (HC), hemolytic uremic syndrome (HUS) dan thrombocytopenia purpura (TPP). Hemorrhagic colitis (HC) merupakan diare berdarah yang disertai dengan kejang perut, HUS ditandai dengan kegagalan ginjal secara akut, trombositopenia, dan anemia hemolitik, sedangkan TPP memiliki gejala mirip pada HUS namun gejala syaraf dan demam lebih menonjol pada TPP.

Ternak sapi merupakan pembawa VTEC yang keluar bersama feses secara intermiten. Pengeluaran VTEC secara intermiten menyebabkan kejadian di lapang sangat sedikit. Walapun kejadianya sangat sedikit, keberadaan VTEC patut diperhatikan mengingat dampak yang ditimbulkan pada manusia. Suwito (2009) melaporkan kejadian VTEC pada susu sapi di Kabupaten Bogor 0,94\%, Sukabumi 2,20\%, sedangkan di Cianjur tidak ditemukan. Sementara itu, E. coli yang diisolasi dari daging sapi yang dijual di pasar tradisional di kota Bogor belum diketahui sifat toksisitasnya terhadap sel Vero. Oleh karena itu, tujuan dari penelitian ini adalah untuk mengetahui toksisitas isolat $E$. coli dari daging sapi yang di jual di beberapa pasar tradisional di wilayah kota Bogor.

\section{Bahan dan Metode}

\section{Bakteri acuan dan sampel penelitian}

Bakteri acuan sebagai kontrol positif digunakan E.coli O157:K88 (BCC.B 2431), sedangkan E.coli K12K99- (Institute of Medical and Veterinary Science Adelaide, Australia) sebagai kontrol negatif. Sampel yang digunakan dalam penelitian ini adalah koleksi isolat $E$. coli yang diisolasi dari daging sapi yang dijual di beberapa pasar tradisional di wilayah kota Bogor.

\section{Konfirmasi $E$. Coli}

Sebanyak 35 isolat $E$. coli ditanam dalam $15 \mathrm{ml}$ brain heart infusion broth (BHI) (Oxoid Ltd., Basingstoke, United Kingdom) dan diinkubasikan pada suhu $37^{\circ} \mathrm{C}$ selama 24 jam. Subkultur pada MacConkay agar (MCA) (Oxoid Ltd., Basingstoke, United Kingdom) dan diinkubasikan pada suhu $37^{\circ} \mathrm{C}$ selama 24 jam. Koloni yang tampak pink diambil sebanyak 5 koloni untuk dilakukan pengecatan Gram dan diidentifikasi lanjut kearah E. coli (Barrow dan Feltham, 1993).

\section{Supernatan $E$. coli}

Isolat $E$. coli terpilih ditanam dalam $10 \mathrm{ml}$ BHI (Oxoid Ltd., Basingstoke, United Kingdom) dan diinkubasikan pada suhu $37^{\circ} \mathrm{C}$ selama 24 jam sambil dikocok dengan kecepatan $100 \mathrm{rpm}$ per menit. Selanjutnya kultur tersebut dimasukkan dalam tabung sentrifuse polyethylene (Nalgene), kemudian disentrifus (Beckman) dengan kecepatan 8000 rpm selama 30 menit pada suhu $4^{0} \mathrm{C}$. Sebanyak $2-4 \mathrm{ml}$ supernatan dipisahkan dan difilter dengan ukuran $0,45 \mu \mathrm{m}$ (PolyLabo, Molsheim, France). Selanjutnya supernatan tersebut disimpan pada suhu $-20^{\circ} \mathrm{C}$ sampai saatnya diuji pada sel Vero satu lapis (monolayer).

\section{Kultur Jaringan Sel Vero Monolayer.}

Sel Vero yang secara rutin dipelihara di bagian kultur jaringan Virologi Balai Penelitian Veteriner Bogor digunakan dalam penelitian ini. Sel Vero yang sudah konfluen sebelumnya dicuci 3 kali menggunakan PBS deionized atau yang tidak mengandung ion $\mathrm{Ca}^{2+}$ dan $\mathrm{Mg}^{2+}$. Selanjutnya dilakukan trypsinasi dengan menambahkan antibiotic trypsin versene (ATV) sebanyak $1,5 \mathrm{ml}$ atau $0,5 \mathrm{ml}$, kemudian diinkubasikan pada suhu $37^{\circ} \mathrm{C}$ selama 5 menit dan diamati dibawah mikroskop inverted. Kemudian ditambahkan Dulbecco Minimal Essential Medium (DMEM) (Sigma-aldrich, Milano, Italy) yang mengandung Fetal Bovine Serum 5\% (JRH Biosciences 12103 ACSL Company) dan $50 \mu \mathrm{g} / \mathrm{ml}$ Gentamicin (Gibco 15710-064). Selanjutnya dengan menggunakan mikropipet multichanel kita masukan sebanyak $100 \mu$ l per well dalam mikrotiter plate 96 dasar rata (Nunch, Roshilde, Denmark) dan diinkubasikan pada suhu $37^{\circ} \mathrm{C}, 5 \% \mathrm{CO}_{2}$ selama 24 jam. Setelah inkubasi diamati dengan mikroskop inverted, apabila per sel Vero sudah tampak konfluen monolayer maka siap digunakan untuk menguji cairan supernatan dari kultur cair isolat E. coli.

\section{Uji Supernatan E. coli dalam Sel Vero Monolayer.}

Uji sitotoksitas dari supernatan E. coli menggunakan metode (Pradel et al., 2000). Supernatan yang sudah disiapkan diencerkan dalam 96 well mikrotiter plate dasar rata yang berisi DMEM (Sigmaaldrich, Milano, Italy) $100 \mu$ dan diencerkan secara serial. Sebanyak $50 \mu$ l tiap-tiap enceran supernatan $E$. coli ditambahkan ke dalam sel Vero satu lapis monolayer dalam 96 well mikrotiter plate. Inkubasi pada $37^{\circ} \mathrm{C}$, $5 \% \mathrm{CO}_{2}$ selama 48 jam dan sel dicuci dengan deionized PBS. Titer toksin ditentukan berdasarkan hasil pengamatan pada enceran tertinggi supernatan yang diujikan yang menimbulkan perubahan morfologi pada sel Vero.

\section{Hasil dan Pembahasan}

Sebelum diuji coba sifat toksisitasnya terhadap sel vero, maka dari 35 isolat $E$. coli di kultur dalam media MCA dan tampak koloninya berwarna pink (Gambar 1). Warna pink tersebut menunjukkan bahwa 
isolat tersebut mampu memfermentasi laktosa dalam waktu 24 jam, dan bakteri tersebut adalah E. coli. Salah satu sifat dari $E$. coli yaitu mampu memfermentasi laktosa dalam waktu 24 jam (Barrow dan Feltham, 1993). Sebagian besar dari E.coli berada dalam saluran pencernaan hewan dan manusia merupakan flora normal, namun ada yang bersifat patogen yang dapat menyebabkan diare pada manusia dan hewan.

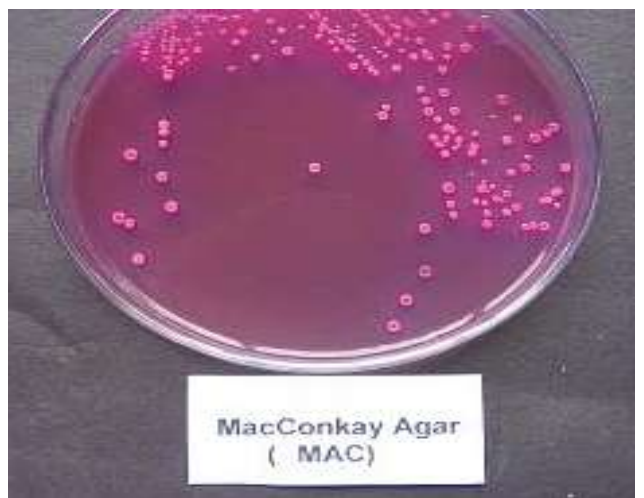

A
Pengecatan Gram dari koloni yang berwarna pink pada media MCA tersebut tampak berbentuk batang pendek dan termasuk bakteri Gram negatif (Gambar 1). E.coli termasuk dalam Famili: Enterobacteriaceae, Genus: Escherichia, bersifat aerob, berbentuk batang, biasanya mempunyai flagella untuk alat gerak dan termasuk kelompok

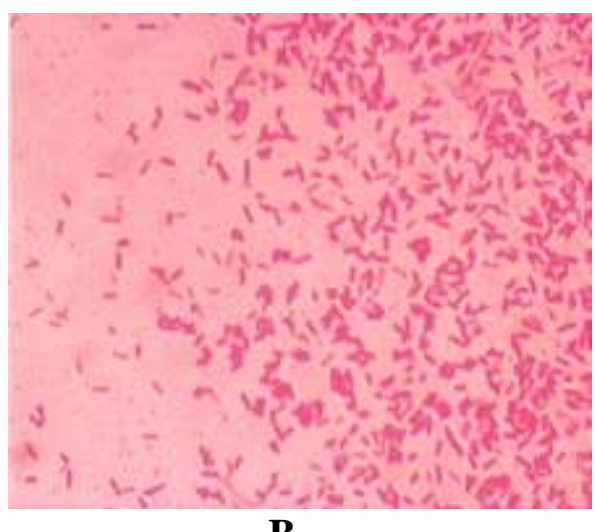

Gambar 1. A. Isolat E. coli dalam media MAC umur 24 jam setelah

B. E. coli umur 24 jam Setelah Pengecatan Gram (Perbesaran 10 x 10)

E. coli verotoksigenik (VTEC) merupakan strain yang bersifat patogenik berasal dari feses sapi. E.coli O157:H7 bersifat verotoksigenik yang merupakan salah satu penyebab keracunan pangan asal ternak. Salah satu untuk mengetahui $E$. coli bersifat verotoksigenik yaitu dengan mengujikan supernatan isolat $E$. coli menggunakan sel Vero. Supernatan dari ke-35 isolat $E$. coli setelah diuji toksisitasnya terhadap sel Vero disajikan dalam (Tabel 1)

Tabel 1. Reaksi Sel Vero Terhadap Supernatan E. coli setelah 48 jam

\begin{tabular}{|c|c|c|c|c|c|c|c|c|c|c|c|}
\hline \multirow{2}{*}{ Asal isolat } & & \multicolumn{10}{|c|}{ Enceran supernatan menyebabkan perubahan morfologi } \\
\hline & & - & $1: 2$ & $1: 4$ & $1: 8$ & $1: 16$ & $1: 32$ & $1: 64$ & $1: 128$ & $1: 256$ & $1: 512$ \\
\hline Pasar Bogor & 3 & 2 & 1 & - & - & - & - & - & - & - & - \\
\hline Pasar Anyar & 25 & $\begin{array}{l}2 \\
4\end{array}$ & 1 & - & - & - & - & - & - & - & - \\
\hline Pasar Jambu Dua & 7 & 7 & - & - & - & - & - & - & - & - & - \\
\hline Jumlah & 35 & $\begin{array}{l}3 \\
3\end{array}$ & 2 & - & - & - & - & - & - & - & - \\
\hline
\end{tabular}

Sel Vero yang dirusak oleh supernatan isolat $E$. coli tanpa diencerkan sebanyak 33 isolat, dan diencerkan 1:2 sebanyak 2 isolat (Tabel 1). Hasil tersebut menunjukkan bahwa sebagian besar supernatan isolat $E$. coli hanya mampu merusak sel Vero tanpa diencerkan. Pada penelitian ini tidak dilakukan penghitungan secara kuantitatif kadar veroktoksin yang terdapat dalam supernatan yang diujikan pada sel Vero, tetapi berdasarkan sitopatik atau perubahan pada sel Vero yaitu tampak keriput, dan mengecil jika dibandingkan dengan sel Vero yang tidak diberi supernatan. Sementara itu, untuk menentukan sifat verotoksigenik dari isolat $E$. coli selain mampu merusak sel Vero juga ditentukan tingkat pengenceran dari supernatan $E$. coli yang masih mampu merusak sel Vero. Hal tersebut sesuai dengan peryataan dari Pradel et al., (2000) bahwa E. coli bersifat verotoksigenik apabila mampu merusak sel Vero pada pengenceran >1:64. Supernatan E. coli yang hanya mampu merusak sel Vero tanpa diencerkan atau pada pengenceran $\langle 1: 2$, maka tidak termasuk dalam kelompok $E$. coli verotoksigenik. Oleh karena supernatan dari ke35 isolat $E$. coli tersebut hanya mampu merusak sel Vero pada pengenceran $<1: 2$, maka semua isolat $E$. coli tersebut tidak termasuk verotoksigenik. Sementara itu 
penelitian Suwito (2009) menunjukkan bahwa kejadian $E$. coli verotoksigenik dalam susu sangat kecil. Hal tersebut disebabkan oleh kecilnya prevalensi E. coli verotoksigenik yang dikeluarkan melaui feses sapi. Bakteri E. coli verotoksigenik dikeluarkan dari saluran pencernaan sedikit sekali bila dibandingkan dengan $E$. coli yang lain sehingga prevalensi dalam produk ternak sangat sedikit (Wasteson, 2001). Heuvelink et al., (1998) menyatakan kejadian VTEC O157:H7 pada susu kurang dari 0,3\% dengan prevalensinya 0-10\%. Prevalensi VTEC pada ternak di kabupaten Sleman Yogyakarta sebanyak 35\% (Hanif et al., 2003). Di luar negeri dilaporkan bahwa prevalensi VTEC pada susu sebanyak $10 \%$, keju $1,5 \%$, daging sapi $3,7 \%$, babi $1,5 \%$, unggas 1,5\%, kambing 2\%, domba 2,5\% (Pradel et al., 2000; Doyle dan Schoeni, 1987). Prevalensi pada manusia di Amerika Serikat dilaporkan sebanyak 5-10\%, Spanyol 2,5\%, dan Prancis 34\% (Blanco et al., 2004; Pradel et al., 2000).

Perubahan morfologi pada sel Vero setelah diuji dengan supernatan E. coli akan berubah menjadi keriput, dan mengecil jika dibandingkan dengan sel Vero yang tidak diberi supernatan (Gambar 2).

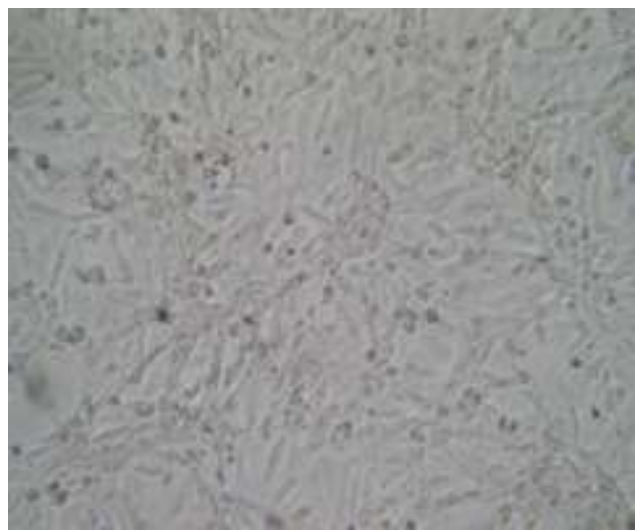

A

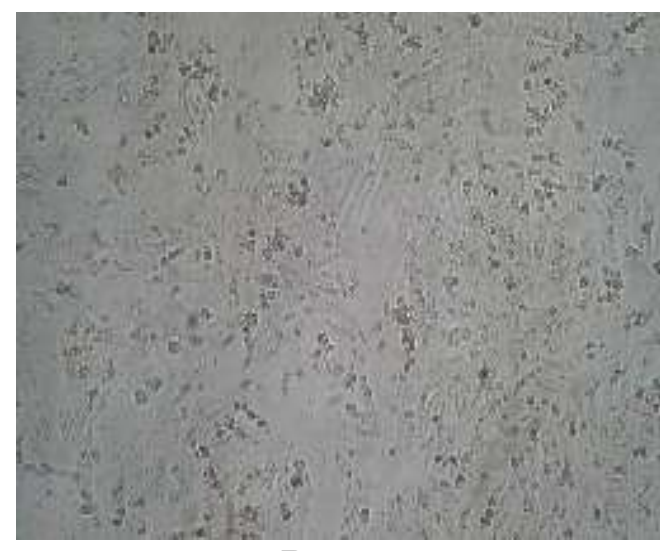

B

Gambar 2. Reaksi sel Vero terhadap supernatan E. coli.

A. Sel Vero monolayer pada umur 24 jam sebelum diberi supernatan isolat E. coli $(16 \times 10)$.

B. Sel Vero monolayer pada umur 24 jam setelah diberi supernatan isolat E. coli O157:H7 ATTCC 43894 (16x10).

Sel Vero yang rusak oleh supernatan E.coli, maka isolat E.coli tersebut mampu menghasilkan verotoksin yang bersifat merusak sel vero sehingga disebut dengan verotoksigenik. Verotoksin merupakan faktor virulensi yang penting dalam patogenesis. Selain verotoksin, faktor virulensi lainnya antara lain hemolisin. Hemolisin merupakan faktor virulensi yang mampu menghemolisis sel darah merah. E.coli yang menghasilkan hemolisin atau bersifat hemolitik dapat juga bersifat verotoksigenik. Penelitian Kusmiyati dan Supar (1998) menunjukkan bahwa E.coli hemolitik penyebab diare pada anak sapi penderita diare berdarah dari Kabupaten Bogor, Sukabumi, dan Bandung bersifat verotoksigenik. Faktor virulensi yang penting dari E.coli dalam menimbulkan penyakit ada 2 macam yaitu intimin dan enterohemolisin. Intimin berperan dalam attaching dan effacing atau perlekatan pada mukosa usus, sedangkan enterohemolisin berperan dalam terjadinya lesi pada permukaan usus sehingga terjadi diare berdarah (Nataro et al., 2004). Produksi enterohemolisin ada 2

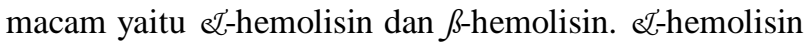
diproduksi pada saat bakteri sedang tumbuh, sedangkan $\beta$-hemolisin dilepaskan bakteri pada saat fase degradasi dan kematian (Mainil, 1999).

\section{Kesimpulan}

Isolat E.coli dari daging sapi asal pasar tradisional di Kota Bogor tidak menghasilkan verotoksin atau tidak mampu merusak sel Vero sehingga tidak bersifat verotoksigenik yang kemungkinan menghasilkan faktor virulensi lainnya dalam menimbulkan penyakit.

\section{Ucapan Terima Kasih}

Ucapan terima kasih disampaikan kepada teknisi bagian Bakteriologi dan Virologi di Balai Besar Penelitian Veteriner Bogor yang sudah banyak membantu selama penelitian berlangsung.

\section{Daftar Pustaka}

Barrow, G.I., \& Feltham, R.K.A. (1983). Cowan and steel's manual for the identification of medical bacteria. Cambridge, Cambridge University Press., 145 pp. 
Blanco, M., Blanco, J.E., Mora, A., Dahbi, G., \& Coira, M.A. (2004). Serotypes, virulence gene, and intimin types of shiga toxin (verotoxin)producing E.coli isolates from catle in Spain and identification of a new intimin variant gen. Journal of Clininical Microbiology, 42 (2):645651. DOI:10.1128/JCM.

Doyle, M.P., \& Schoeni, J.L. (1987). Isolation of Escherichia coli 0157:H7 from retail fresh meats and poultry. Applied Environmental Microbiology, 53(10):2394-2396.

Gomes, T.A., Hernandes, R.T., Torres, A.G., Salvador, F.A., Guth, B.E.C., Vaz, T.M., Irino, K., Silva, R.M., \& Vieira, M.A. (2011). Adhesinencoding genes from Shiga toxin-producing Escherichia coli are more prevalent in atypical than in typical enteropathogenic E. coli. Journal of Clinical Microbiology, (49):3334-333710. DOI: $10.1128 /$ JCM.00779-11.

Hanif, S.K.S., Sumiarto, B., \& Budiharta, S. (2003). Prevalensi dan analisis faktor-faktor infeksi $E$. coli O157: H7 sapi perah rakyat di kabupaten sleman. Jurnal Sain Veteriner, 21(1): 50-54.

Heuvelink, Bleumink, B., Biggellaar, F.L.A., Giffel, M.C., Beumer, R., \& Boer, E. (1998). Occurrence and survival of verocytotoxin producing E.coli $\mathrm{O} 157$ in raw cow's milk in the Netherland. Journal of Food Protection, 61(12): 1597-1601.

Konowalchuk, J., Speirs, J.I, \& Starvic, S. (1977). Vero response to a cytotoxin of Escherichia coli. Infection and Immunity, 18(3): 775-779.

Kusmiyati \& Supar. (1998). E. coli verotoksigenik dari anak sapi perah penderita diare. Proceding. Seminar hasil-hasil penelitian veteriner. Pusat penelitian peternakan. Bogor. Pebruari. 103108.

Karmali, M.A., Gannon, V., \& Sargeant, J.M. (2010). Review: Verocytotoxin-producing Escherichia coli (VTEC). Veterinary Microbiology, 140(34): 360-370.

DOI:https://doi.org/10.1016/j.vetmic.2009.04.011.

Mainil, J. (1999). Shiga/Verocytotoxins and Shiga/ Verotoxigenic Escherichia coli in animals. Veterinary Research, 30(2-3): 235-257.
Nataro, J.P., Kaper, J.B., \& Mobley, H.L. (2004). Pathogenic Escherichia coli. Nature Reviews Microbiology, 2 (7) : 123-140.

DOI: http://dx.doi.org/10.1038/nrmicro 818.

Pradel, N., Livrelli,V., Champs, C., Palcoux, J.B., Reynaud, A., Scheutz, F., Sirot, J., Joly, B., \& Forestier, C. (2000). Prevalence and characterization of shiga toxin-producing $E$. coli isolated from cattle, food, and children during a one year prospective study in France. Journal of Clinical Microbiology, Maret 38(3):1023-1031.

DOI: https://jcm.asm.org/content/38/3/1023

Suwito,W. (2009). Escherichia coli Verotoksigenik (VTEC) yang diisolasi dari susu sapi. Jurnal Ilmu Ternak \& Veteriner, 14(3):237-243.

Wasteson, B.Y. (2001). Zoonotic Escherichia coli. Acta Veterinaria Scandinavia. 95:79-84. DOI: https://doi.org/10.1186/1751-0147-43-S1$\underline{\mathrm{S} 79}$ 